\title{
PREPARATION FOR IMPLEMENTATION OF INDUSTRY 4.0 IN SMALL AND MEDIUM-SIZED ENTERPRISES OF METAL INDUSTRY
}

\author{
'Dorota KLIMECKA-TATAR, ${ }^{1}$ Manuela INGALDI, ${ }^{1}$ Robert ULEWICZ, ${ }^{2}$ Renata DWORNICKA \\ ${ }^{1}$ Czestochowa University of Technology, Czestochowa, Poland, EU, \\ d.klimecka-tatar@pcz.pl, manuela.ingaldi@wz.pcz.pl, robert.ulewicz@pcz.pl \\ ${ }^{2}$ Krakow Uniwersity of Technology, Krakow, Poland, EU, renata.dwornicka@pk.edu.pl
}

https://doi.org/10.37904/metal.2021.4301

\begin{abstract}
Changing market conditions, the emergence of new technologies and new solutions make it necessary to introduce changes in enterprises. One of the changes that enterprises have to face is Revolution 4.0, also known as industry 4.0. It is more difficult in enterprises of the metallurgical industry due to the specificity of production and technology, but also old technological equipment, no employees, no base for foreign employees. The main goal of this paper is to evaluate SMEs from the metal industry in terms of their ability to overcome the barriers they face during implementation of Industry 4.0 assumptions and principles. In the research the current state of the metallurgical enterprises from the SME sector and the problems they have to face taking into account the assumption of the Industry 4.0.
\end{abstract}

Keywords: Industry 4.0, metallurgical industry, SME's, Revolution 4.0, barriers

\section{INTRODUCTION}

The market demand for metal products, invariably for many decades, is very high, and the competitiveness of enterprises in the metal industry forces the introduction of very large changes in both the method of enterprise management and production control. These changes result not only from the dynamic development of new technologies, but also from the way processes are organized $[1,2]$. Enterprises taking care of their market position are already striving to introduce new management principles based on the assumptions of sustainable development (care for raw materials and the environment), as well as the principles respected by Industry 4.0 and even 5.0. The most important factors that determine Industry 4.0 include the smoothness of production based on interoperability [3-6]. According to the assumptions, companies that want to compete in the market created by Industry 4.0 must first of all ensure an appropriate level of information transparency in relation to the automation and robotization of production. Quick access to data and the ability to react immediately can largely affect the efficiency and flexibility of processes and the competitiveness of new products introduced to the market. Many companies in the metal industry, despite the need to change, still use old technologies, the effectiveness of which is unquestionable $[7,8]$. And they are still reluctant to face the industrial revolution. Any changes, both organizational and technological, regardless of the way in which they are introduced, face numerous barriers. In the world literature, research and descriptions relating to barriers to modern solutions and technologies are widely discussed. In general, there are many groups of barriers, and the most common are: technological, economic, social and mental. These areas are the key elements that require reflection when implementing changes in the operating strategy of the metal industry. It is obvious that the strength of the barriers in enterprises from the metal industry is characterized by a specific set of factors that are presented in Table 1. However, there are theories that openness to Industry 4.0 leads to the perception of higher barriers. Additionally, the knowledge and willingness to acquire the skills to overcome the economic barrier often result in a strong improvement in results [9-12]. 
Table 1 Types of barriers causing resistance to the implementation of modern principles and solutions in SMEs from the metallurgical industry

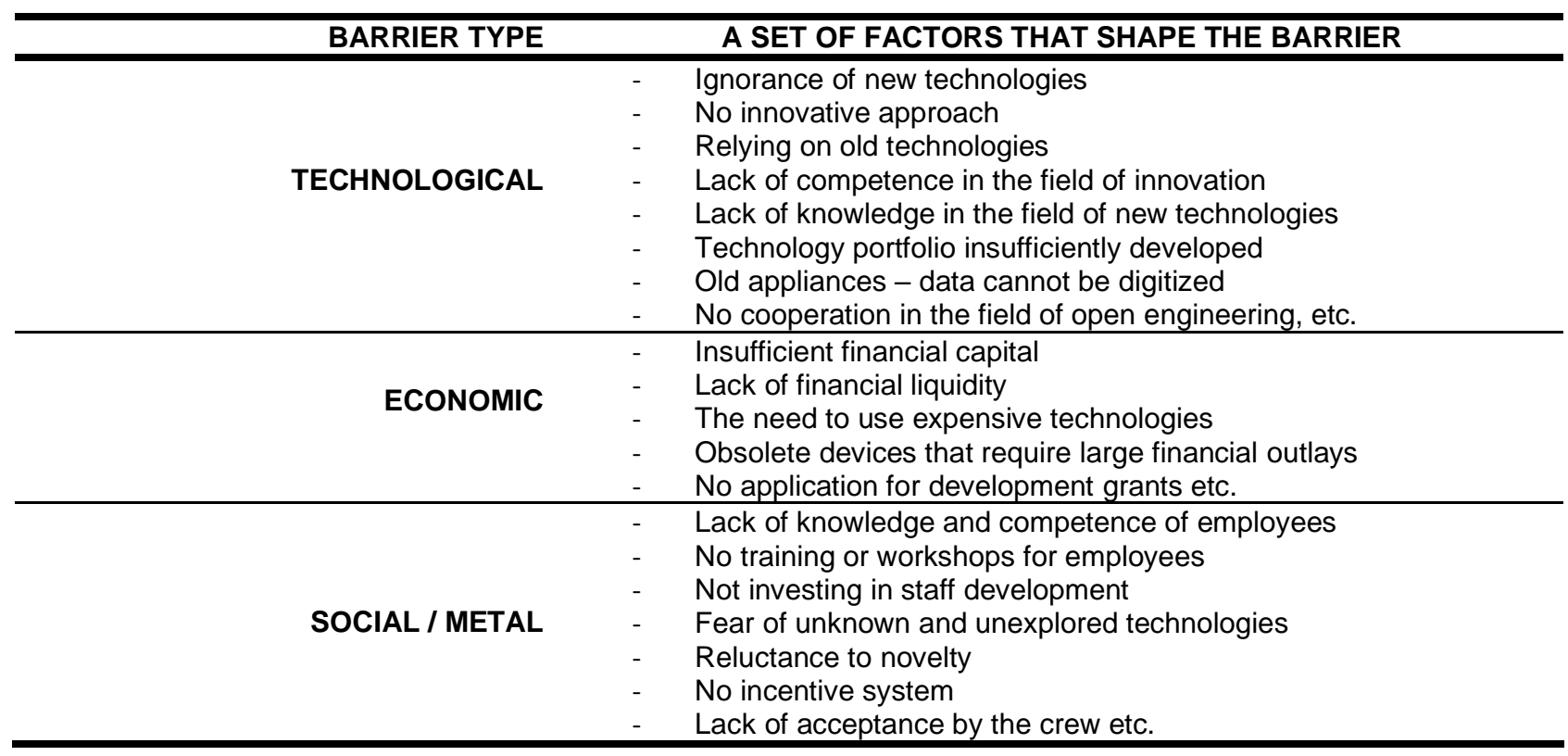

In addition to the factors constituting some kind of resistivity in the area of implementing changes should also be taken into account. The ease of overcoming difficulties, as it is known, may be determined by the company's capital, management effectiveness (efficiency of management systems), competences of employees and management, the motivation system, technological position of the enterprise, management principles and policies, etc. $[13,14]$. It is obvious that it is much easier to overcome all barriers by large enterprises (corporations, etc.) than by small and medium-sized enterprises (SMEs), and even more by micro-enterprises [15-18]. The main goal of this paper is to evaluate SMEs from the metal industry in terms of their ability to overcome the barriers they face during implementation of Industry 4.0 assumptions and principles.

The subject of the article is primarily of interest to technologists $[19,20]$ and automotive engineers [21,22], but also should be inspiring for biotechnology industry [23,24], quality engineers [25-27] and people dealing with environmental optimization [27,29]. The collected information is potential valuable source for methodologists dealing with process organization and optimization [30,31].

\section{METHODOLOGY}

The presented research results are part of a larger research project related to the implementation of Industry 4.0 in various SME enterprises in Poland. In the paper the results for metallurgical enterprises from the SME sector in southern Poland were presented. It is possible to indicate the level of preparation of enterprises for the implementation of Industry 4.0 and the main problems that these enterprises have faced in this process. The research was conducted in January-December 2020 in 139 enterprises.

The research was divided into two parts. Initially, enterprises were asked to evaluate the current state, this part took the form of a survey form. At the beginning, representatives of these enterprises evaluated the level of automation and robotization of individual operations on a scale of 1-5, where 1 meant manual-machine processes, 5 - full automation and robotization. For the purposes of this paper, the following transformation of the ratings was made: $1-0.1 ; 2-0.3 ; 3-0.5 ; 4-0.7 ; 5-0.9$ (Figure 1a). Then, the respondents were supposed to indicate whether the instruments and methods are used in their enterprise by selecting one of the following answers: I do not know, no, sometimes, yes. In this case, the transformation was as follows: I don't know - 0.1; no - 0.3; sometimes 0.7 ; yes - 0.9. (Figures $1 \mathbf{b}-1 \mathrm{~d}$ ). The results are presented in the form of radar charts. The second part of the research was in the form of a direct interview, where the same representatives 
were asked to indicate the biggest problems that are encountered during the implementation of individual assumptions of Industry 4.0. These results are presented as bar graphs.

\section{RESULTS AND DISCUSSION}

The level of automation and robotization of individual operations in the production process was presented in Figure 1. The highest level of automation and robotization was recorded in the case of production operations (0.4), yet it cannot be assessed as high, which means that on average, in the metallurgical industry companies, machine production can be found more often. It is related to the specifics of the industry. Many technologies have been used for many years. The current state of the enterprises was presented in Figure. It can be seen that many enterprises use product modelling programs or modelling production processes programs, which makes it easier to plan and organize the production process. Many companies also use identification of products, tools and materials in the system, which eliminates wasted time.

a)

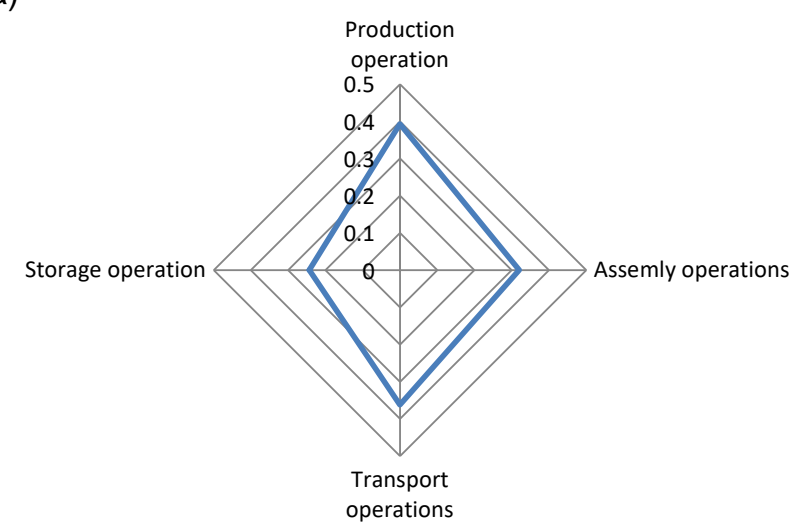

c)

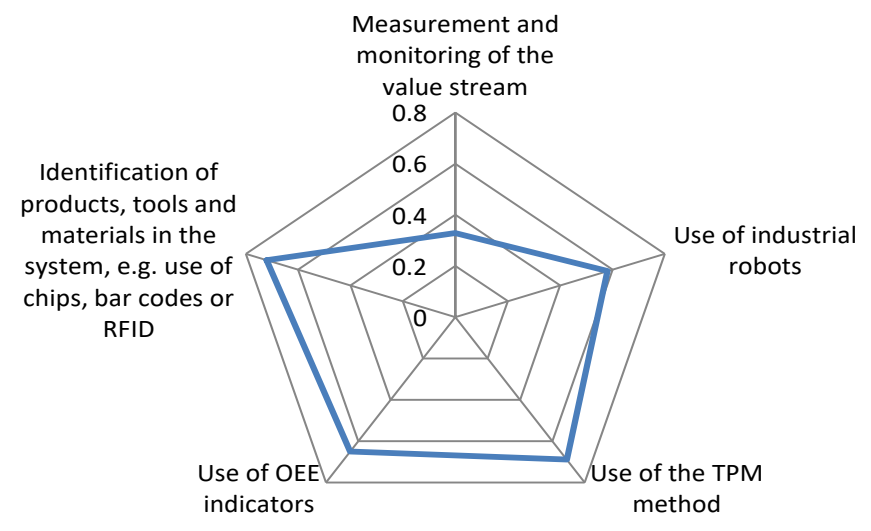

b)

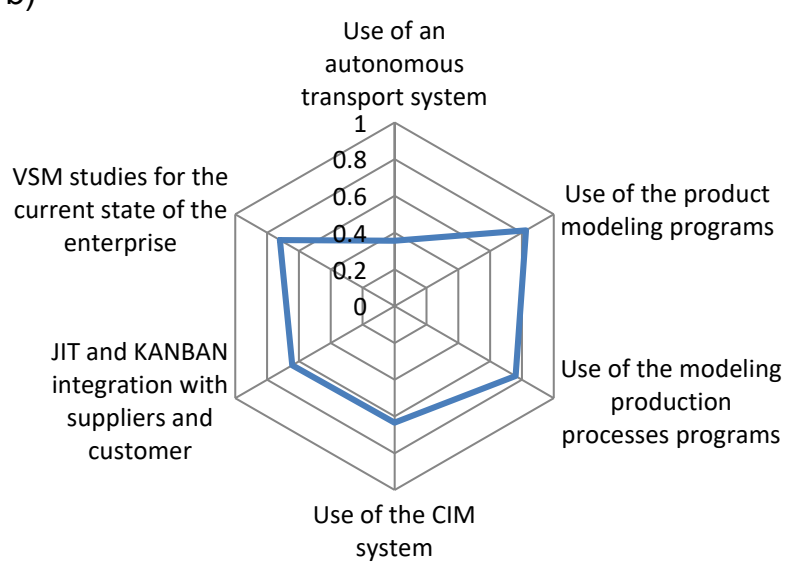

d)

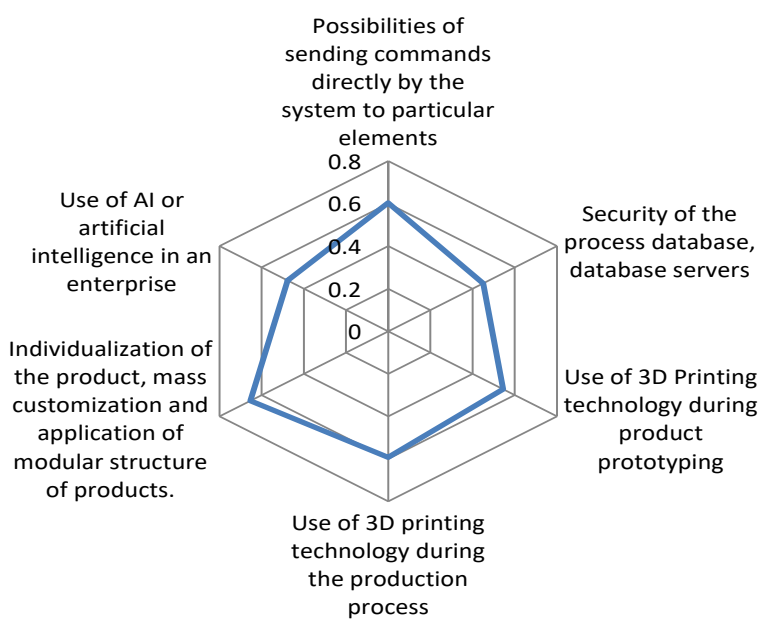

Figure 1 (a) The level of automation and robotization of individual operations; (b), (c), (d) Assessment of the current state in the research enterprises

There have been many problems related to the various solutions used in Industry 4.0 (Figures 2-4). When it comes to the automation and robotization of individual processes, the respondents primarily indicated the need to employ foreign employees, too old and incompatible equipment. There is a problem with employees on Polish market cause by the fact that many specialists moved to other countries, for example Western European. So Polish enterprises, also from metallurgical sector, need to search for employees from abroad. 
But at the same time other problems appear e.g., language barriers or lack of infrastructure for those people. If it comes to old equipment, to introduce automation and robotization there is a need to change also current machines, because they are so old that they do not want to collaborate with the newest solutions.

If it comes to problems indicated in Figure 3, one should pay attention to high cost of acquiring specialist, language problems of foreign employees, continuous staff rotation and no adequate monitoring equipment. Again, it is possible to observe to problem with staff which is very common in Poland. New employees need to learn how to conduct individual operations, very often they need special courses. The problem is not only problem with language but also additional cost if the enterprise needs to train new employees over and over again. Lack of monitoring equipment means not enough money to buy it.

The enterprises also encounter many problems when implementing various types of production tools and systems (Figure 4). Between the problems it should be mentioned resistance of employees to changes, continuous staff rotation, language barriers for foreign employees and lack of pull system.

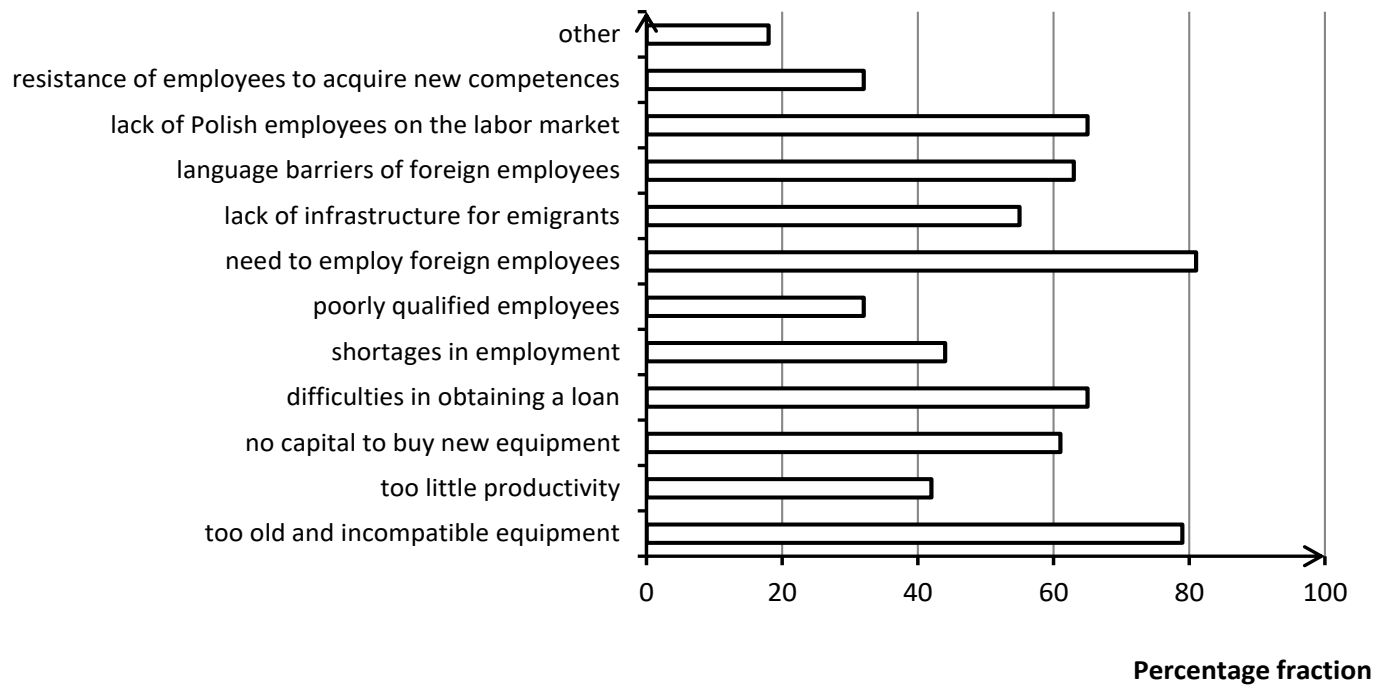

Figure 2 Obstacles associated with increasing the level of automation and robotization of different processes in enterprises

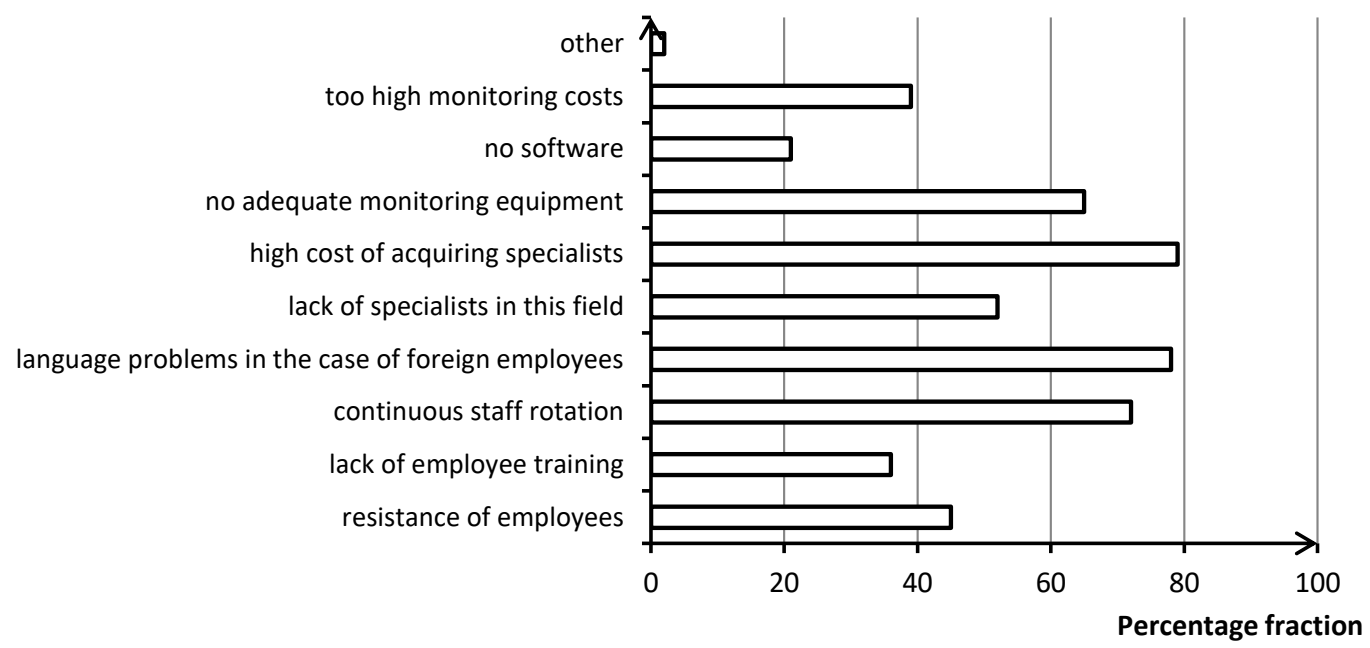

Figure 3 Problems with monitoring processes, documenting and selling data and their use in the field of process improvement and optimization, and with monitoring and supervision over the material, product and 


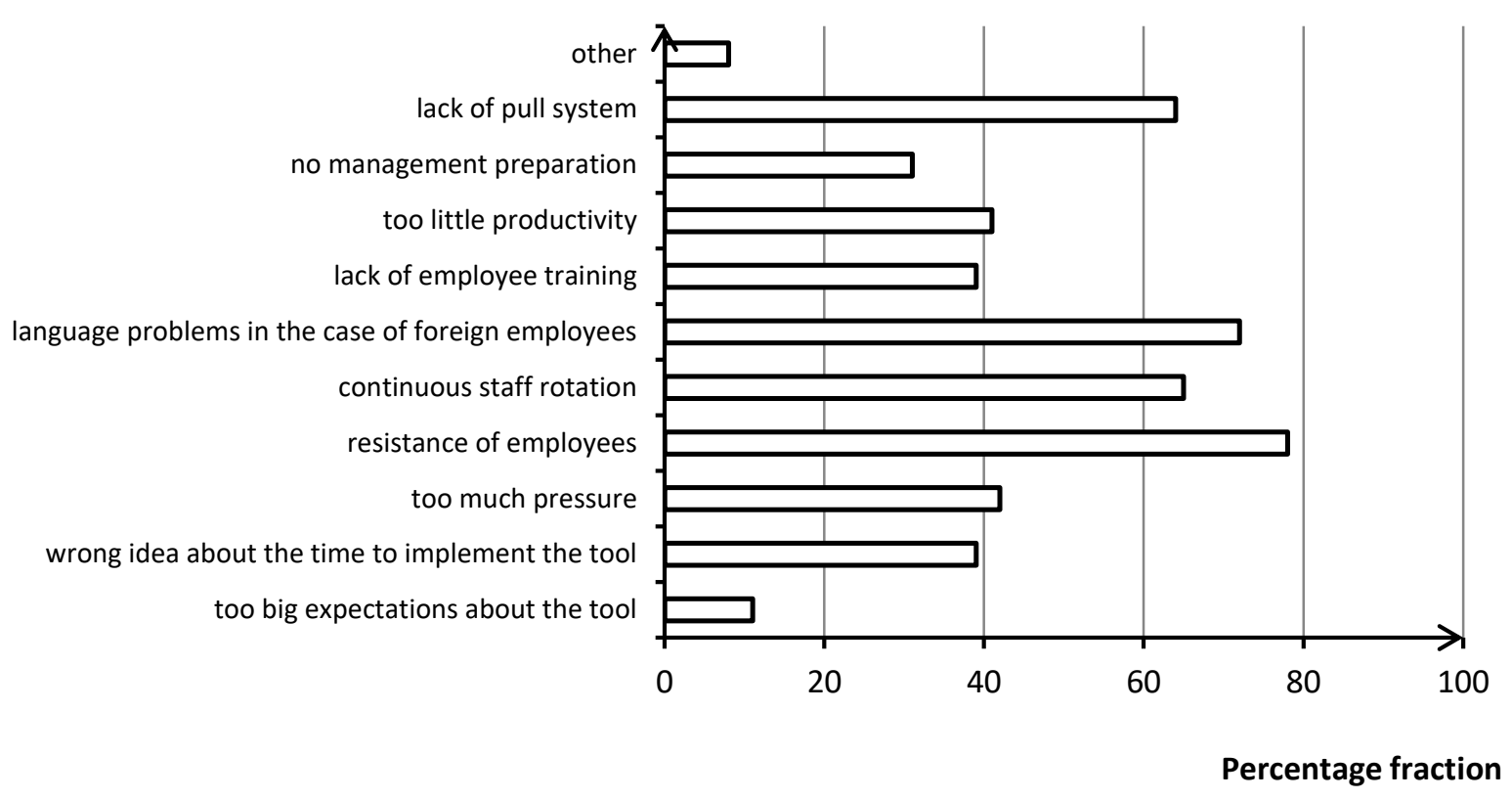

Figure 4 Problems when implementing various systems

The last element is needed in case of many production systems but is connected with big changes in production organization. Problems with employees are difficult to solve. Often, with many types of change, employees are against, because they are afraid of the new solutions. It is also hard to make changes if employees are constantly struggling or have language problems. All this is not conducive to revolutions.

\section{CONCLUSION}

Introducing changes in any enterprise is very difficult, but inevitable. Industry 4.0 brings a lot of modern solutions that are not only to facilitate the production process, but also to introduce many organizational changes. These changes are a big challenge for metallurgical enterprises from the SME sector due to the level of their automation and robotization as well as the financial resources available. In the paper several problems faced by the metallurgical industry, with an emphasis on small and medium-sized enterprises, were indicated. Between them, it should be mentioned old technologies and the lack of automation and robotization of processes. As a result, it is difficult to use the latest solutions that would be compatible with the technical equipment that is in the enterprise. Another problem is the lack of specialists in the labor market. The constant rotation of employees, and a large outflow of Polish employees to Western Europe meant that Polish enterprises have to look for foreign employees, most often from the East. Unfortunately, there are language barriers, there is no adequate infrastructure for these employees, they need to be trained, sent to additional specialist courses, which, unfortunately, is associated with high costs. This means that these enterprises do not have the simple path of transformation to Industry 4.0, it is related to the economic factor and the human factor.

\section{REFERENCES}

[1] GOMES, J.G.C., OKANO, M.T., OTOLA, I. Creation of indicators for classification of business models and business strategies in production systems. Polish Journal of Management Studies. [online]. 2020, vol. 22, pp. 142-157, Available from: https://doi.org/10.17512/pjms.2020.22.2.10.

[2] GRABARA, J. Sustainable Development - Never Fulfilled Dream. Quality Access to Success. 2019, pp. 565-570.

[3] INGALDI, M., ULEWICZ, R. Problems with the Implementation of Industry 4.0 in Enterprises from the SME Sector. Sustainability. [online]. 2020, vol. 12, no. 217, Available from: https://doi.org/10.3390/su12010217. 
[4] PATTANAPAIROJ, S., NITISIRI, K., SETHANAN, K. A Gap Study between Employers' Expectations in Thailand and Current Competence of Master's Degree Students in Industrial Engineering under Industry 4.0. Production Engineering Archives. [online]. 2021, vol. 27, pp. 50-57, Available from: https://doi.org/10.30657/pea.2021.27.7.

[5] PIETRASZEK, J., RADEK, N., GOROSHKO, A.V. Challenges for the DOE methodology related to the introduction of Industry 4.0. Production Engineering Archives. [online]. 2020, vol. 26, pp. 190-194. Available from: https://doi.org/10.30657/pea.2020.26.33.

[6] TIEP, N.C., OANH, T.T.K., THUAN, T.D., VAN TIEN, D., VAN HA, T. Industry 4.0, Lean Management and organizational support: a case of supply chain operations. Polish Journal of Management Studies. [online]. 2020, vol. 22, pp. 583-594. Available from: https://doi.org/10.17512/pjms.2020.22.1.37.

[7] MOR, R.S., KUMAR, D., YADAV, S., JAISWAL, S.K. Achieving cost efficiency through increased inventory leanness: Evidence from manufacturing industry. Production Engineering Archives. [online]. 2021, vol. 27, pp. 4249. Available from: https://doi.org/10.30657/pea.2021.27.6.

[8] OTOLA, I. The Impact of Resources Meeting VRIN Criteria on the Economic Performance of Enterprises. Th International Conference on Changes in Social and Business Environment (CISABE' 2018). Book Series: Changes in Social and Business Environment-Kaunas. 2018, pp. 69-74.

[9] CUGNO, M., CASTAGNOLI, R., BÜCHI, G. Openness to Industry 4.0 and performance: The impact of barriers and incentives. Technological Forecasting and Social Change. [online]. 2021, vol. 168, 120756. Available from: https://doi.org/10.1016/j.techfore.2021.120756.

[10] CHAUHAN, C., SINGH, A., LUTHRA, S. Barriers to industry 4.0 adoption and its performance implications: An empirical investigation of emerging economy. Journal of Cleaner Production. [online]. 2021, vol. 285, 124809. Available from: https://doi.org/10.1016/j.jclepro.2020.124809.

[11] KARRACH, L., PIVARČIOVÁ, E. Recognition of Data Matrix Codes in Images and their Applications in Production Processes. Management Systems in Production Engineering. [online]. 2020, vol. 28, pp. 154-161. Available from: https://doi.org/10.2478/mspe-2020-0023.

[12] TKACHENKO, V., KLYMCHUK, M., TKACHENKO, I. Recursive and Convergence Methodology of the Investment Management of the Enterprise Digitalization Processes. Management Systems in Production Engineering. [online]. 2021, vol. 29, pp. 14-19. Available from: https://doi.org/10.2478/mspe-2021-0002.

[13] KLIMECKA-TATAR, D., NICIEJEWSKA, M. Small-sized enterprises management in the aspect of organizational culture. Revista Gestão \& Tecnologia. [online]. 2021, vol. 21, pp. 4-24, Available from: https://doi.org/10.20397/2177-6652/2021.v21i1.2023.

[14] KLIMECKA-TATAR, D., INGALDI, M. Assessment of the Technological Position of a Selected Enterprise in the Metallurgical Industry. Materials Research Proceedings. 2020, vol. 17, pp. 72-78.

[15] BAJDOR, P., PAWEŁOSZEK, I., FIDLEROVA, H. Analysis and Assessment of Sustainable Entrepreneurship Practices in Polish Small and Medium Enterprises. Sustainability. [online]. 2021, vol. 13, 3595. Available from: https://doi.org/10.3390/su13073595.

[16] MOKHTAR, S.S.S., MAHOMED, A.S.B., AZIZ, Y.A., RAHMAN, S.A. Industry 4.0: the importance of innovation in adopting cloud computing among SMEs in Malaysia. Polish Journal of Management Studies. [online]. 2020, vol. 22, pp. 310-322. Available from: https://doi.org/10.17512/pjms.2020.22.1.20.

[17] TEPLICKÁ, K., HURNÁ, S. New Approach of Costs of Quality According their Trend of During Long Period in Industrial Enterprises in SMEs. Management Systems in Production Engineering. [online]. 2021, vol. 29, pp. 2026. Available from: https://doi.org/10.2478/mspe-2021-0003.

[18] NICIEJEWSKA, M., KIRILIUK, O. Occupational health and safety management in "small size" enterprises, with particular emphasis on hazards identification. Production Engineering Archives. [online]. 2020, vol. 26, pp. 195201. Available from: https://doi.org/10.30657/pea.2020.26.34.

[19] ANTOSZ, K., PACANA, A. Comparative analysis of the implementation of the SMED method on selected production stands. Tehnicki Vjesnik. 2018, vol. 25, pp. 276-282.

[20] PACANA, A., SIWIEC, D., BEDNAROVA, L., Analysis of the incompatibility of the product with fluorescent method. Metalurgija. 2019. vol. 58, pp. 337-340.

[21] PATEK, M., KONAR, R., SLADEK, A., RADEK, N. Non-destructive testing of split sleeve welds by the ultrasonic TOFD method. Manuf. Technol. 2014, vol. 14, pp. 403-407. 
[22] PACANA A., CZERWIŃSKA K., BEDNAROWA L. Comprehensive improvement of the surface quality of the diesel engine piston. Metalurgija. 2018. vol. 58, pp. 329-332.

[23] SKRZYPCZAK-PIETRASZEK, E., SKRZYPCZAK, L., WESOLOWSKA, M. Gentiana tibetica King from tissue culture. Scientia Pharmaceutica. 1993, vol. 61, pp. 287-296.

[24] SKRZYPCZAK-PIETRASZEK, E., URBANSKA, A., ZMUDZKI, P., PIETRASZEK, J. Elicitation with methyl jasmonate combined with cultivation in the Plantform ${ }^{\mathrm{TM}}$ temporary immersion bioreactor highly increases the accumulation of selected centellosides and phenolics in Centella asiatica (L.) Urban shoot culture. Engineering in Life Sciences. 2019. vol. 19, pp.931-943.

[25] GAZDA, A., PACANA, A., MALINDŽÁK, D. Study on improving the quality of stretch film by Taguchi method. Przem. Chem. 2013, vol. 92, pp. 980-982.

[26] PACANA, A., GAZDA, A., MALINDZAK, D., STEFKO, R. Study on improving the quality of stretch film by Shainin method. Przem. Chem. 2014, vol. 93, pp. 243-245.

[27] PIETRASZEK, J., GOROSHKO, A. The heuristic approach to the selection of experimental design, model and valid pre-processing transformation of DoE outcome. Adv. Mater. Res.-Switz. 2014, vol. 874, pp. 145-149.

[28] MAJEWSKI, G., TELEJKO, M., ORMAN, Ł.J. Preliminary results of thermal comfort analysis in selected buildings. E3S Web of Conf. 2017, vol. 17, art. 56.

[29] MAJEWSKI, G., ORMAN, Ł.J., TELEJKO, M., RADEK, N., PIETRASZEK, J., DUDEK, A. Assessment of thermal comfort in the intelligent buildings in view of providing high quality indoor environment. Energies. 2020, vol. 13, art. 1973.

[30] PACANA, A., CZERWIŃSKA, K., DWORNICKA, R. Analysis of non-compliance for the cast of the industrial robot basis. In: METAL 2019: $28^{\text {th }}$ Int. Conf. on Metall. and Mater. Ostrava: TANGER, 2019, pp. 644-650.

[31] ULEWICZ, R., MAZUR, M., KNOP, K., DWORNICKA, R. Logistic controlling processes and quality issues in a cast iron foundry. Materials Research Proceedings. 2020, vol. 17, pp. 65-71. 